\title{
Gefitinib frequently induces liver damage in patients with lung adenocarcinoma previously treated by chemotherapy
}

This article was published in the following Dove Press journal:

Lung Cancer:Targets and Therapy

8 June 2013

Number of times this article has been viewed

\author{
Yasoo Sugiura' \\ Etsuo Nemoto' \\ Osamu Kawai ${ }^{2}$ \\ Yasuyuki Ohkubo ${ }^{2}$ \\ Hisae Fusegawa ${ }^{2}$ \\ Shizuka Kaseda' \\ 'Department of Pulmonary and \\ Thoracic Surgery, ${ }^{2}$ Department \\ of Respiratory Medicine, Kanagawa \\ National Hospital, Hadano, Japan
}

Correspondence: Yasoo Sugiura National Hospital Organization Kanagawa National Hospital, 666 Ochiai, Hadano, Kanagawa 257-8585, Japan

Tel +8 | 463 8| I 77|

Fax +8I 46382 I 774

Email yasoos@hotmail.com
Background: Gefitinib is known as one of the agents for treating patients with both advanced lung cancer and an epidermal growth-factor receptor mutation. In the epidermal growth-factor receptor-mutant advanced non-small-cell lung cancer population, gefitinib therapy has been associated with increased response rate, longer progression-free survival, and better quality of life compared to other anticancer drugs. However, gefitinib has to be discontinued for patients in whom adverse events occur, even if it is still effective. Here, we retrospectively assessed the clinical course of patients receiving gefitinib therapy, with a particular focus on liver damage.

Patients and methods: Of 24 Asian patients treated with $250 \mathrm{mg}$ gefitinib daily at Kanagawa National Hospital, Japan, between January 2008 and June 2012, grade 3 liver damage (Common Terminology Criteria for Adverse Events, version 4.0) occurred in nine and were eligible for our assessment. The regimen was subsequently changed to alternate-day administration. The relationships between liver damage and each clinical factor were retrospectively examined using Fisher's exact test.

Results: Of the nine patients with liver damage, seven had previous exposure to another anticancer drug. There was a significant relationship between the incidence of liver damage and previous chemotherapy $(P=0.009)$. The objective response rates of patients treated with daily gefitinib $250 \mathrm{mg}$ and alternate-day gefitinib following liver damage were $66.7 \%$ and $46.7 \%$, respectively; these were not significantly different $(P=0.597)$.

Conclusion: Gefitinib for advanced adenocarcinoma patients who have previously undergone chemotherapy should be used cautiously and liver function monitored closely, because it frequently induces significant liver damage. The alternate-day administration of gefitinib may be a suitable option for patients in whom daily gefitinib therapy induces liver damage.

Keywords: gefitinib, liver damage, adjuvant chemotherapy, previous chemotherapy, alternateday administration

\section{Introduction}

Gefitinib is a valuable therapeutic agent for patients with both advanced lung cancer and an epidermal growth-factor receptor (EGFR) mutation. As per the guidelines of the American Society of Clinical Oncology and the Japan Lung Cancer Society, it is recommended as a first-line treatment for patients with advanced non-small-cell lung cancer (NSCLC) and an EGFR mutation. ${ }^{1}$ However, gefitinib therapy often needs to be discontinued due to the occurrence of adverse events, even if it remains clinically effective. In this retrospective study, we assessed the clinical course of patients receiving gefitinib therapy, with a particular focus on the extent of liver damage induced by the drug. 


\section{Patients and methods}

\section{Patients}

The present study was a retrospective analysis of all patients with pathologically proven adenocarcinoma who were treated at Kanagawa National Hospital, Japan, between January 2008 and June 2012. A total of 24 Asian patients (16 women, eight men, age 55-89 years, median 67 years) received gefitinib $250 \mathrm{mg} /$ day; of these, ten patients had postoperative recurrence, while 14 patients had advanced inoperable cancer (Table 1). On admission, written informed consent was obtained from all patients in accordance with institutional guidelines based on the Helsinki Declaration. The relevant institutional review board approved this study.

\section{Methods}

Follow up assessments included physical examination, complete blood counts, blood chemistry evaluated every 2-4 weeks, and tumor assessment by computed tomography performed every 1-2 months.

Hepatitis B virus (HBV) surface antigen was detected by enzyme immunoassays as a serological marker of HBV infection, and anti-hepatitis $\mathrm{C}$ virus (HCV) antibody screening was performed using a chemiluminescent enzyme immunoassay (Ortho-clinical Diagnostics, Tokyo, Japan) before biopsy and/or surgical procedures in our hospital.

The tumor response was assessed as complete response (CR), partial response (PR), stable disease for $\geq 12$ weeks (SD), or progressive disease (PD), in accordance with the standard guidelines for Response Evaluation Criteria In Solid Tumors. ${ }^{2}$ Adverse events were evaluated using Common Terminology Criteria For Adverse Events version $4.0^{3}$ (CTCAE). Liver damage was defined as elevation of serum levels of either liver or biliary enzymes. If a grade 3 adverse event occurred, daily administration of gefitinib was ceased and switched to alternate-day administration $(250 \mathrm{mg} /$ dose $)$ after the serum levels of liver and biliary enzymes returned to the normal range.

For comparisons of proportions, Fisher's exact test was used. All results were considered significant at $P<0.05$. All statistical analyses were performed using Stat Mate IV software version 4.01 (ATM, Tokyo, Japan).

\section{Results}

Patient characteristics are detailed in Table 1.
Table I Clinical characteristics of patients

\begin{tabular}{|c|c|c|c|}
\hline & \multicolumn{2}{|c|}{ Previous } & \multirow[t]{2}{*}{ Total } \\
\hline & + & - & \\
\hline \multicolumn{4}{|l|}{ Sex } \\
\hline Female & 7 & 9 & 16 \\
\hline Male & 3 & 5 & 8 \\
\hline \multirow[t]{2}{*}{ Age in years (median) } & $56-89$ & $55-83$ & $55-89$ \\
\hline & $(64)$ & $(67)$ & $(67)$ \\
\hline \multicolumn{4}{|l|}{ Smoking status } \\
\hline Never smoked & 6 & 8 & 14 \\
\hline Current smoker & 2 & 2 & 4 \\
\hline Former smoker & 2 & I & 3 \\
\hline Unknown & 0 & 3 & 3 \\
\hline \multicolumn{4}{|l|}{ Hepatitis virus } \\
\hline $\begin{array}{l}\text { Hepatitis B virus antigen- } \\
\text { positive }\end{array}$ & 0 & 0 & 0 \\
\hline $\begin{array}{l}\text { Hepatitis } C \text { virus antibody- } \\
\text { positive }\end{array}$ & I & 0 & I \\
\hline \multicolumn{4}{|l|}{ Alcohol consumption } \\
\hline Nondrinker & 8 & 7 & 15 \\
\hline Social drinker & I & 3 & 4 \\
\hline $0-20 \mathrm{~g} / \mathrm{day}^{\mathrm{a}}$ & 0 & 0 & 0 \\
\hline $20-40 \mathrm{~g} /$ day $^{\mathrm{a}}$ & I & I & 2 \\
\hline$\geq 40$ g/day ${ }^{\mathrm{a}}$ & 0 & 0 & 0 \\
\hline Unknown & 0 & 3 & 3 \\
\hline \multicolumn{4}{|l|}{ Histology } \\
\hline Adenocarcinoma & 10 & 14 & 24 \\
\hline \multicolumn{4}{|l|}{ EGFR mutation } \\
\hline Exon 18 G7I9X & I & 0 & I \\
\hline Exon 19 deletion & I & 7 & 8 \\
\hline Exon 2I L858R & 4 & 3 & 7 \\
\hline None & 2 & I & 3 \\
\hline Unknown & 2 & 3 & 5 \\
\hline \multicolumn{4}{|l|}{ Operative and inoperative cases } \\
\hline $\begin{array}{l}\text { Postoperative recurrent or } \\
\text { metastatic cases }\end{array}$ & 4 & 6 & 10 \\
\hline Inoperative advanced cases & 6 & 8 & 14 \\
\hline \multicolumn{4}{|l|}{ Performance status } \\
\hline 0 & 8 & 7 & 15 \\
\hline I & 2 & 4 & 6 \\
\hline 2 & 0 & I & I \\
\hline 3 & 0 & 2 & 2 \\
\hline 4 & 0 & 0 & 0 \\
\hline \multicolumn{4}{|l|}{ Metastasis or recurrence site ${ }^{b}$} \\
\hline Bone & 3 & 5 & 8 \\
\hline Pleurisy & 2 & 4 & 6 \\
\hline Lung & 3 & 3 & 6 \\
\hline Lymph node & 3 & 3 & 6 \\
\hline Brain & 0 & 3 & 6 \\
\hline Adrenal gland & 2 & 0 & 2 \\
\hline Liver & I & 0 & I \\
\hline $\begin{array}{l}\text { Only tumor marker } \\
\text { elevation }\end{array}$ & 2 & 0 & 2 \\
\hline
\end{tabular}

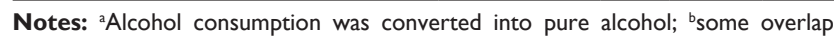
present.

Abbreviation: EGFR, epidermal growth-factor receptor. 


\section{Hepatitis virus infection, smoking history, and alcohol consumption}

Only one patient tested positive for $\mathrm{HCV}$ antibodies; the remaining patients showed negative results for $\mathrm{HBV}$ antigen and $\mathrm{HCV}$ antibodies. With regard to smoking status, the number of current smokers was four, there were three former smokers, and 14 patients had never smoked. The smoking status of the remaining three patients was unknown. With respect to alcohol consumption, the number of nondrinkers was 15 , social drinkers four, and habitual drinkers (consuming pure alcohol $\geq 30.8 \mathrm{~g} /$ day) two.

\section{EGFR mutation status}

The following EGFR mutations were observed: exon 18 G719X $(n=1)$, exon 19 deletion $(n=8)$, and exon 21 L858R $(n=7)$. Three patients had no EGFR mutations, while the EGFR mutation status of five was not examined. The Eastern Cooperative Oncology Group Performance Status ${ }^{4}$ was graded $0-1$ in 21 cases and 2-3 in three patients. Of the 24 patients, ten patients had previously undergone chemotherapy, while 14 were chemotherapynaive. All patients were initially treated with $250 \mathrm{mg}$ gefitinib daily. CTCAE grade 3 liver damage occurred in nine of these patients; thereafter, the same dose was administered on alternate days.

\section{Previous chemotherapy}

Previous chemotherapy regimens as first-line therapy included the following: cisplatin (CDDP) $80 \mathrm{mg} / \mathrm{m}^{2}$ plus docetaxel (DOC) $60 \mathrm{mg} / \mathrm{m}^{2}(\mathrm{n}=2)$, CDDP $75 \mathrm{mg} / \mathrm{m}^{2}$ plus pemetrexed sodium $(\mathrm{PEM}) 500 \mathrm{mg} / \mathrm{m}^{2}(\mathrm{n}=2)$, carboplatin $(\mathrm{CBDCA})$ (area under the curve $=5 \mathrm{mg} / \mathrm{mL} / \mathrm{minute}$ ) plus PEM
$500 \mathrm{mg} / \mathrm{m}^{2}(\mathrm{n}=1)$, CBDCA area under the curve $=5 \mathrm{mg} / \mathrm{mL}$ plus DOC $60 \mathrm{mg} / \mathrm{m}^{2}(\mathrm{n}=1)$, CDDP $75 \mathrm{mg} / \mathrm{m}^{2}$ plus PEM $500 \mathrm{mg} / \mathrm{m}^{2}$ and bevacizumab $15 \mathrm{mg} / \mathrm{kg}(\mathrm{n}=1)$, gemcitabine (GEM) $1000 \mathrm{mg} / \mathrm{m}^{2}$ and vinorelbine (VNR) $25 \mathrm{mg} / \mathrm{m}^{2}$ $(\mathrm{n}=1)$, and tegafur-uracil $250 \mathrm{mg} / \mathrm{m}^{2}$ a day for 2 years $(n=2) .{ }^{5-10}$ Previous chemotherapy regimens as second-line therapy included the following: GEM plus VNR $(n=1)$, PEM $500 \mathrm{mg} / \mathrm{m}^{2}(\mathrm{n}=1)$, and DOC $60 \mathrm{mg} / \mathrm{m}^{2}(\mathrm{n}=1) .{ }^{11,12} \mathrm{In}$ four postoperative patients who underwent adjuvant therapy, two patients received tegafur-uracil, one patient was treated with CBDCA and PEM, and one patient was administered CDDP and PEM (Table 2).

\section{Adverse events}

Nine patients suffered CTCAE grade 3 liver damage, which occurred within 35-386 days (median 105 days) after the initiation of gefitinib therapy. The interval between cessation of gefitinib therapy and the normalization of the serum levels of both liver and biliary enzymes ranged from 7 to 22 days (median 13) (Table 3). Of the nine patients with liver damage, seven had previously been treated with other anticancer agents. The incidence of gefitinib-induced liver damage was significantly related to previous chemotherapy $(P=0.009$, Tables 4 and 5).

Furthermore, skin rash occurred in ten patients $(41.7 \%)$, liver damage in nine $(37.5 \%)$, diarrhea in four $(16.7 \%)$, and acute lung injury in two $(8.3 \%)$ following gefitinib therapy.

\section{Objective response rate}

Overall, two patients achieved CR and eleven patients achieved PR. SD and PD were achieved in four and seven patients, respectively, as the best response. The objective

Table 2 Chemotherapy regimens before gefitinib treatment, alcohol history, and hepatitis virus

\begin{tabular}{|c|c|c|c|c|}
\hline $\begin{array}{l}\text { Liver damage } \\
\text { induced by gefitinib }\end{array}$ & $\begin{array}{l}\text { Ist regimen before } \\
\text { gefitinib therapy }\end{array}$ & $\begin{array}{l}\text { 2nd regimen before } \\
\text { gefitinib therapy }\end{array}$ & Alcohol consumption & Hepatitis virus \\
\hline \multirow[t]{7}{*}{ Occurred } & $\mathrm{CDDP}+\mathrm{DOC}^{\mathrm{a}}$ & - & Nondrinker & Negative \\
\hline & CDDP + PEM & $\mathrm{DOC}^{\mathrm{a}}$ & Nondrinker & Negative \\
\hline & $\mathrm{CDDP}+\mathrm{PEM}^{\mathrm{a}}$ & $\mathrm{GEM}+\mathrm{VNR}^{\mathrm{a}}$ & $30.8 \mathrm{~g} /$ day & Negative \\
\hline & $\mathrm{CBDCA}+\mathrm{PEM}^{\mathrm{a}}$ & - & Nondrinker & Negative \\
\hline & $C B D C A+D^{\circ} C^{b}$ & - & Nondrinker & $\mathrm{HCV}$ \\
\hline & $\mathrm{UFT}^{\mathrm{b}}$ & - & Nondrinker & Negative \\
\hline & $\mathrm{UFT}^{\mathrm{b}}$ & - & Nondrinker & Negative \\
\hline \multirow[t]{3}{*}{ Did not occur } & $\mathrm{CDDP}+\mathrm{DOC}^{\mathrm{a}}$ & PEM $^{a}$ & Social drinker & Negative \\
\hline & $\mathrm{CDDP}+\mathrm{PEM}+\mathrm{BEV}^{\mathrm{a}}$ & - & Nondrinker & Negative \\
\hline & GEM + VNR ${ }^{a}$ & - & Nondrinker & Negative \\
\hline
\end{tabular}

Notes: a Chemotherapy for postoperative recurrence or inoperative cases; ${ }^{b}$ postoperative adjuvant chemotherapy.

Abbreviations: CDDP, cisplatin; DOC, docetaxel; PEM, pemetrexed sodium; GEM, gemcitabine; VNR, vinorelbine; CBDCA, carboplatin; UFT, tegafur-uracil; BEV, bevacizumab; $\mathrm{HCV}$, hepatitis $\mathrm{C}$ virus. 
Table 3 Patient characteristics of subjects receiving alternate-day gefitinib therapy following liver damage

\begin{tabular}{|c|c|c|c|c|c|c|c|c|}
\hline $\begin{array}{l}\text { Age } \\
\text { (years) }\end{array}$ & Sex & $\begin{array}{l}\text { Alcohol } \\
\text { consumption }\end{array}$ & $\begin{array}{l}\text { Hepatitis } \\
\text { virus }\end{array}$ & $\begin{array}{l}\text { Previous } \\
\text { chemotherapy }\end{array}$ & $\begin{array}{l}\text { Type of EGFR } \\
\text { mutation }\end{array}$ & $\begin{array}{l}\text { Days from initiating } \\
\text { gefitinib treatment } \\
\text { to cessation }\end{array}$ & $\begin{array}{l}\text { Cessation } \\
\text { (days) }\end{array}$ & $\begin{array}{l}\text { Response } \\
\text { rate }\end{array}$ \\
\hline 64 & $\mathrm{~F}$ & Nondrinker & None & - & Exon 19 deletion & 35 & 13 & $C R$ \\
\hline 64 & $\mathrm{~F}$ & Nondrinker & None & + & Exon 21 L858R & 36 & 7 & PR \\
\hline 81 & $\mathrm{~F}$ & Nondrinker & Unknown & - & Exon 19 deletion & 39 & 14 & PD \\
\hline 88 & $M$ & Nondrinker & None & + & Exon 21 L858R & 92 & 19 & SD \\
\hline 62 & $\mathrm{~F}$ & Nondrinker & None & + & Exon 21 L858R & 105 & 10 & $S D$ \\
\hline 62 & $\mathrm{~F}$ & $30.8 \mathrm{~g} /$ day & None & + & Unknown & 118 & 14 & PR \\
\hline 80 & $M$ & Nondrinker & None & + & Exon 21 L858R & 341 & 22 & PR \\
\hline 70 & $\mathrm{~F}$ & Nondrinker & $\mathrm{HCV}$ & + & Exon 18 G7I9X & 355 & 10 & PR \\
\hline 60 & $\mathrm{~F}$ & Nondrinker & None & + & Exon 19 deletion & 386 & 7 & PR \\
\hline
\end{tabular}

Abbreviations: EGFR, epidermal growth-factor receptor; CR, complete response; PR, partial response; SD, stable disease; PD, progressive disease; HCV, hepatitis $C$ virus.

response rates (ORRs) in all patients, patients with liver damage, and patients without liver damage were $54.2 \%, 66.7 \%$, and $46.7 \%$, respectively (Table 6). ORRs for patients treated with daily gefitinib $(250 \mathrm{mg} /$ day $)$ and alternate-day gefitinib did not differ significantly $(P=0.597)$.

\section{Discussion}

The Iressa Pan-Asia Study demonstrated the noninferiority of gefitinib compared with CBDCA plus paclitaxel chemotherapy in terms of progression-free survival. ${ }^{13} \mathrm{In}$ some clinical studies of patients with EGFR mutations, gefitinib as first-line therapy led to a higher ORR and greater improvements in quality of life compared with CBDCA plus paclitaxel. ${ }^{14-18}$ These reports supported that EGFRmutant patients with advanced lung adenocarcinoma should receive an EGFR tyrosine kinase inhibitor (TKI) as first-line therapy. ${ }^{15,19,20}$

Some patients with completely resected NSCLC receive postoperative adjuvant chemotherapy that does not include EGFR TKI, but rather comprises CDDP-based anticancer drugs, despite the presence of EGFR mutations. ${ }^{21}$ When recurrence or metastasis is clarified, EGFR-mutant

Table 4 Relationship between liver damage and each clinical factor

\begin{tabular}{lllll}
\hline & & \multicolumn{2}{c}{ Liver damage } & \multirow{2}{*}{$P$-value } \\
\cline { 3 - 4 } & & + & - & \\
\hline Sex & Female/male & $7 / 2$ & $9 / 6$ & 0.324 \\
PS & $0,1 / 2,3$ & $8 / 1$ & $13 / 2$ & 0.692 \\
Operation & $+/-$ & $4 / 5$ & $6 / 9$ & 0.739 \\
Skin rash & $+/-$ & $5 / 4$ & $5 / 10$ & 0.260 \\
Diarrhea & $+/-$ & $2 / 7$ & $2 / 13$ & 0.870 \\
Previous & $+/-$ & $7 / 2$ & $3 / 12$ & $0.009^{*}$ \\
chemotherapy & & & & \\
\hline
\end{tabular}

Notes: Liver damage was significantly correlated with previous chemotherapy according to Fisher's exact test. $* P<0.05$.

Abbreviation: PS, performance status. patients as well as patients with advanced NSCLC with EGFR mutations should receive an EGFR TKI as first-line therapy. Thus, we typically encounter patients with advanced NSCLC who have undergone previous chemotherapy as well as chemotherapy-naive patients in clinical practice.

In patients with gefitinib-induced liver damage, low-dose gefitinib treatment is efficacious; however, the clinical course and factors related to gefitinib-induced liver damage remain unknown. ${ }^{22,23}$ Therefore, in the present study, we assessed the clinical factors related to gefitinib-induced liver damage in patients with inoperable advanced cancer or postoperative recurrence at a single general hospital.

Previous chemotherapy was significantly related to gefitinib-induced liver damage $(P=0.009$, odds ratio $=14.0$ ). No significant relationship was observed between gefitinib-induced liver damage and sex, performance status, postoperative recurrence or inoperable cancer, presence of skin rash and diarrhea, and the type of EGFR mutation (Tables 2 and 3). Among the ten postoperative recurrence patients who underwent postoperative adjuvant chemotherapy, liver damage occurred in four patients (40\%). Therefore, it is important to monitor carefully the serum levels of liver and biliary enzymes during gefitinib treatment for patients who have previously received chemotherapy.

Table 5 Relationship between previous chemotherapy and each adverse event

\begin{tabular}{lllll}
\hline & \multicolumn{2}{l}{$\begin{array}{l}\text { Previous } \\
\text { chemotherapy }\end{array}$} & P-value & Odds ratio \\
\cline { 2 - 3 } & + & - & & \\
\hline Liver damage & 7 & 2 & $0.009 *$ & 14 \\
Skin rash & 4 & 6 & 0.780 & 0.89 \\
Diarrhea & 2 & 2 & 0.853 & 1.5 \\
Acute lung injury & $\mathrm{I}$ & $\mathrm{I}$ & 0.802 & 1.4 \\
\hline
\end{tabular}

Note: Previous chemotherapy was significantly correlated with gefitinib-induced liver damage (odds ratio $=14$ ). $* P<0.05$. 
Table 6 Objective response rate in patients administered daily gefitinib and alternate-day gefitinib following liver damage

\begin{tabular}{llll}
\hline & $\begin{array}{l}\text { Gefitinib } \\
\mathbf{2 5 0} \mathbf{~} \mathbf{m g} \text { /day }\end{array}$ & Reduced dose & Total \\
\hline RECIST & & & \\
CR & 1 & 1 & 2 \\
PR & 6 & 5 & $1 \mathrm{I}$ \\
SD & 2 & 2 & 4 \\
PD & 6 & 1 & 7 \\
CR + PR (\%) & $7(46.7)$ & $6(66.7)$ & $13(54.2)$ \\
\hline
\end{tabular}

Abbreviations: RECIST, Response Evaluation Criteria in Solid Tumors; CR, complete response; PR, partial response; SD, stable disease; PD, progressive disease.

Liver damage is more frequently associated with gefitinib than with other chemotherapeutic regimens. Elevation of liver transaminases in grade 3 liver damage occurs at a frequency of $9 \%$ and $1 \%$ in patients treated with gefitinib and CBDCA plus paclitaxel, respectively. ${ }^{13}$ In this study, only one HCV antibody-positive patient was included, while the other patients tested negative for HBV antigen and HCV antibodies; further, alcohol consumption was not excessive in the patient group, as shown in Table 1. Thus, we consider that the reason for the elevations in the serum levels of liver and biliary enzymes was neither hepatitis virus infection nor alcohol consumption. Furthermore, the relevance between liver damage and gefitinib was evaluated using the Digestive Disease Week Japan score, ${ }^{24,25}$ which was modified for Japanese subjects based on the diagnostic criteria of the International Consensus Meeting. ${ }^{26,27}$ The average of the Digestive Disease Week Japan score in our patients was 6.5 (cutoff score $=5$ ). ${ }^{24,25}$ Therefore, we considered that the liver damage observed in the nine patients in our study was caused by gefitinib.

The serum levels of liver and biliary enzymes returned to the normal range within approximately 2 weeks after the cessation of gefitinib therapy (Table 3). However, the recovery period included a bias related to the frequency of assessing these levels. After normalization of these enzyme levels, the alternate-day administration was performed safely. In terms of ORR, no significant differences were observed between patients treated with daily gefitinib and alternate-day gefitinib following liver damage. These results may suggest that treatment with gefitinib on alternate days be continued in such patients, even if liver damage occurs, given the clinical response to gefitinib.

The reason underlying the strong association between gefitinib-induced liver damage and previous exposure to other anticancer drugs remains unknown. ${ }^{28}$ Because the nine patients with liver damage in our study had undergone chemotherapy using other anticancer drugs (eg, CDDP) without any adverse events beyond grade 3 , it is unclear whether these anticancer drugs affected the liver enzyme levels. Gefitinib is metabolized by CYP3A4 and is O-demethylated by CYP2D6 in the liver. ${ }^{29}$ Any anticancer drugs should be reduced or stopped generally in the setting of overt biochemical liver dysfunction, and Miller et al recommended a $50 \%$ dose reduction in erlotinib, another EGFR TKI, for lung adenocarcinoma patients with erlotinibinduced liver damage. ${ }^{30,31} \mathrm{~A}$ liver biopsy would be necessary to assess accurately the mechanism underlying the liver damage induced by gefitinib in patients who have previously undergone chemotherapy.

Finally, based on the present findings, we recommend that the serum levels of liver and biliary enzymes be closely monitored during gefitinib treatment for patients who have received previous chemotherapy. This information may significantly contribute to improved clinical practice in terms of safety for anticancer drug administration to advanced lung cancer patients. Moreover, because alternateday gefitinib treatment could be safely administered in patients in whom daily gefitinib therapy induced liver damage, we consider that this approach may be a suitable option in such patients in whom gefitinib continues to be clinically efficacious.

Our study has certain limitations. Further studies are necessary to confirm our findings, since the patient group in this study was not purely homogeneous, included patients with inoperable advanced cancer as well as those with postoperative recurrence, and had a small sample size because only a single general hospital was screened.

\section{Conclusion}

American Society of Clinical Oncology guidelines indicate that EGFR TKI therapy should be considered as a first-line therapy for patients with both advanced NSCLC and an EGFR mutation. ${ }^{1,32-34}$ With regard to the incidence of adverse events, gefitinib should be cautiously used with monitoring liver function closely for advanced NSCLC patients who have previously undergone chemotherapy, because it frequently induces significant liver damage in such patients. Alternateday administration of gefitinib may be a suitable option for patients in whom daily gefitinib therapy induces liver damage.

\section{Acknowledgments}

The authors would like to thank Editage (http://www.editage.jp) for providing editorial assistance and English-language review.

\section{Disclosure}

The authors report no conflicts of interest in this work. 


\section{References}

1. Keedy VL, Temin S, Somerfield MR, et al. American Society of Clinical Oncology provisional clinical opinion: epidermal growth factor receptor (EGFR) Mutation testing for patients with advanced non-small-cell lung cancer considering first-line EGFR tyrosine kinase inhibitor therapy. J Clin Oncol. 2011;29(15):2121-2127.

2. Eisenhauer EA, Therasse P, Bogaerts J, et al. New response evaluation criteria in solid tumours: revised RECIST guideline (version 1.1). Eur J Cancer. 2009;45(2):228-247.

3. National Cancer Institute, Common Toxicity Criteria [homepage on the Internet]. NCI Common Terminology Criteria for Adverse Events (CTCAE) v.4 data files.] Available from: http://evs.nci.nih.gov/ftp1/ CTCAE/About.html. Accessed on May 12, 2013.

4. Oken MM, Creech RH, Tormey DC, et al. Toxicity And Response Criteria Of The Eastern Cooperative Oncology Group. Am J Clin Oncol. 1982;5(6):649-655.

5. Scagliotti GV, Parikh P, von Pawel J, et al. Phase III study comparing cisplatin plus gemcitabine with cisplatin plus pemetrexed in chemotherapy-naive patients with advanced-stage non-small-cell lung cancer. J Clin Oncol. 2008;26(21):3543-3551.

6. Kubota K, Watanabe K, Kunitoh H, et al. Phase III randomized trial of docetaxel plus cisplatin versus vindesine plus cisplatin in patients with stage IV non-small-cell lung cancer: the Japanese Taxotere Lung Cancer Study Group. J Clin Oncol. 2004;22(2):254-261.

7. Rodrigues-Pereira J, Kim JH, Magallanes M, et al. A randomized phase 3 trial comparing pemetrexed/carboplatin and docetaxel/carboplatin as first-line treatment for advanced, nonsquamous non-small cell lung cancer. J Thorac Oncol. 2011;6(11):1907-1914.

8. Lima AB, Macedo LT, Sasse AD. Addition of bevacizumab to chemotherapy in advanced non-small cell lung cancer: a systematic review and meta-analysis. PLoS One. 2011;6(8):e22681.

9. Tan EH, Szczesna A, Krzakowski M, et al. Randomized study of vinorelbine-gemcitabine versus vinorelbine-carboplatin in patients with advanced non-small cell lung cancer. Lung Cancer. 2005;49(2): 233-240.

10. Kato H, Ichinose Y, Ohta M, et al. A randomized trial of adjuvant chemotherapy with uracil-tegafur for adenocarcinoma of the lung. N Engl J Med. 2004;350(17):1713-1721.

11. Hanna N, Shepherd FA, Fossella FV, et al. Randomized phase III trial of pemetrexed versus docetaxel in patients with non-small-cell lung cancer previously treated with chemotherapy. J Clin Oncol. 2004;22(9): 1589-1597.

12. Mukohara T, Takeda K, Miyazaki M, Takifuji N, Terakawa K, Negoro S. Japanese experience with second-line chemotherapy with low-dose (60 mg/M2) docetaxel in patients with advanced non-small-cell lung cancer. Cancer Chemother Pharmacol. 2001;48(5):356-360.

13. MokTS, Wu YL, Thongprasert S, et al. Gefitinib or carboplatin-paclitaxel in pulmonary adenocarcinoma. $N$ Engl J Med. 2009;361(10): 947-957.

14. Morita S, Okamoto I, Kobayashi K, et al. Combined survival analysis of prospective clinical trials of gefitinib for non-small cell lung cancer with EGFR mutations. Clin Cancer Res. 2009;15(13):4493-4498.

15. Maemondo M, Inoue A, Kobayashi K, et al. Gefitinib or chemotherapy for non-small-cell lung cancer with mutated EGFR. $N$ Engl J Med. 2010;362(25):2380-2388.

16. Mitsudomi T, Morita S, Yatabe Y, et al. Gefitinib versus cisplatin plus docetaxel in patients with non-small-cell lung cancer harbouring mutations of the epidermal growth factor receptor (WJTOG3405): an open label, randomised phase 3 trial. Lancet Oncol. 2010;11(2):121-128.

Lung Cancer: Targets and Therapy

\section{Publish your work in this journal}

Lung Cancer: Targets and Therapy is an international, peer-reviewed, open access journal focusing on lung cancer research, identification of therapeutic targets and the optimal use of preventative and integrated treatment interventions to achieve improved outcomes, enhanced survival and quality of life for the cancer patient. Specific topics covered in the journal include: Epidemiology, detection and screening; Cellular research and biomarkers; Identification of biotargets and agents with novel Submit your manuscript here: http://www.dovepress.com/lung-cancer-targets--therapy-journal
17. Chang $\mathrm{CH}$, Chen KY, Young-Xu Y, et al. The safety and efficacy of gefitinib versus platinum-based doublets chemotherapy as the first-line treatment for advanced non-small-cell lung cancer patients in East Asia: a meta-analysis. Lung Cancer. 2008;62(2):242-252.

18. Oizumi S, Kobayashi K, Inoue A, et al. Quality of life with gefitinib in patients with EGFR-mutated non-small cell lung cancer: quality of life analysis of North East Japan Study Group 002 Trial. Oncologist. 2012;17(6):863-870.

19. Moran T, Sequist LV. Timing of epidermal growth factor receptor tyrosine kinase inhibitor therapy in patients with lung cancer with EGFR Mutations. J Clin Oncol. 2012;30(27):3330-3336.

20. Bria E, Milella M, Cuppone F, et al. Outcome of advanced NSCLC patients harboring sensitizing EGFR mutations randomized to EGFR tyrosine kinase inhibitors or chemotherapy as first-line treatment: a meta-analysis. Ann Oncol. 2011;22(10):2277-2285.

21. Arriagada R, Dunant A, Pignon JP, et al. Long-term results of the international adjuvant lung cancer trial evaluating adjuvant cisplatin-based chemotherapy in resected lung cancer. J Clin Oncol. 2010;28(1):35-42.

22. Satoh H, InoueA, Kobayashi K, et al. Low-dose gefitinib treatment for patients with advanced non-small cell lung cancer harboring sensitive epidermal growth factor receptor mutations. J Thorac Oncol. 2011;6(8): 1413-1417.

23. Fujiwara Y, Kiura K, Toyooka S, et al. Relationship between epidermal growth factor receptor gene mutations and the severity of adverse events by gefitinib in patients with advanced non-small cell lung cancer. Lung Cancer. 2006;52(1):99-103.

24. Watanabe M, Shibuya A. Validity study of a new diagnostic scale for drug-induced liver injury in Japan - comparison with two previous scales. Hepatol Res. 2004;30(3):148-154.

25. Iwasa M, Zeniya M, Kumagi T, et al. Modified diagnostic criteria of drug-induced liver injury proposed by the international consensus meeting. Hepatogastroenterology. 2005;52(63):869-874.

26. Chen J, Gu R, Wang Q, et al. Gefitinib-induced hepatotoxicity in patients treated for non-small cell lung cancer. Onkologie. 2012;35(9): 509-513.

27. Danan G, Benichou C. Causality assessment of adverse reactions to drugs I. A novel method based on the conclusions of international consensus meetings:application to drug-induced liver injuries. J Clin Epidemiol. 1993;46(11):1323-1330.

28. Bussières JF, Habra M. Application of International Consensus Meeting Criteria for classifying drug-induced liver disorders. Ann Pharmacother. 1995;29(9):875-878.

29. Rukazenkov Y, Speake G, Marshall G, et al. Epidermal growth factor receptor tyrosine kinase inhibitors: similar but different? Anticancer Drugs. 2009;20(10):856-866.

30. Field KM, Michael M. Part II: Liver function in oncology: towards safer chemotherapy use. Lancet Oncol. 2008;9(12):1181-1190.

31. Miller AA, Murry DJ, Owzar K, et al. Phase I and pharmacokinetic study of erlotinib for solid tumors in patients with hepatic or renal dysfunction: CALGB 60101. J Clin Oncol. 2007;25(21):3055-3060.

32. Kim ES, Hirsh V, Mok T, et al. Gefitinib versus docetaxel in previously treated non-small-cell lung cancer (INTEREST): a randomised phase III trial. Lancet. 2008;372(9652):1809-1818.

33. Maruyama R, Nishiwaki Y, Tamura T, et al. Phase III study, V-15-32, of gefitinib versus docetaxel in previously treated Japanese patients with non-small-cell lung cancer. J Clin Oncol. 2008;26(26):4244-4252.

34. Lee DH, Park K, Kim JH, et al. Randomized phase III trial of gefitinib versus docetaxel in non-small cell lung cancer patients who have previously received platinum-based chemotherapy. Clin Cancer Res. 2010;16(4):1307-1314.

mechanisms of action; Optimal clinical use of existing anticancer agents, including combination therapies; Radiation and surgery; Palliative care; Patient adherence, quality of life, satisfaction; Health economic evaluations. The manuscript management system is completely online and includes a very quick and fair peer-review system. Visit http://www.dovepress.com/testimonials.php to read real quotes from published authors. 